Lothar de Rossi MD, * Nils-Peter Preußler, * Friedrich K. Pühringer MD, Uwe Klein $\mathrm{MD}^{\star}$

\title{
Onset of neuromuscular block at the masseter and adductor pollicis muscles following rocuronium or succinyl- choline
}

Purpose: To compare the onset time of two different rocuronium doses $\left(0.6\right.$ and $\left.0.9 \mathrm{mg} \cdot \mathrm{kg}^{\mathrm{BI}}\right)$ and succinylcholine ( $1.5 \mathrm{mg} \cdot \mathrm{kg}^{-1}$, preceeded by $0.06 \mathrm{mg} \cdot \mathrm{kg}^{-1}$ rocuronium) at the masseter and the adductor pollicis muscle. Methods: In a randomized study, 60 ASA I or II adult women, 18-65 yr of age, were anesthetized with propofol and fentanyl and nitrous oxide in oxygen. Neuromuscular monitoring was performed using acceleromyography simultaneously on the masseter and adductor pollicis. Onset time was measured at both muscles using supramaximal $0.1 \mathrm{~Hz}$ single twitch stimulation (square-wave pulse $0.2 \mathrm{msec}$ duration).

Results: In all patients, complete neuromuscular block occured at the masseter and adductor pollicis muscles. Lag-time and onset time were faster at the masseter that at the adductor pollicis muscle in both rocuroniumgroups $(P<0.01)$ and in the succinylcholine-group $(P<0.01)$. Furthermore, onset time was more rapid after $0.9 \mathrm{mg} \cdot \mathrm{kg}^{-1}$ rocuronium $(65 \pm 7 \mathrm{~s})$ than after succinylcholine $(83 \pm 19 \mathrm{sec})$ at the AP $(P<0.05)$, but did not differ at the masseter $(33 \pm 6$ vs $36 \pm 7 \mathrm{sec})$.

Conclusions: Following rocuronium and succinylcholine, onset time is faster at the masseter than at the adductor pollicis muscle.

Objectif : Comparer la rapidité d'action de deux doses différentes de rocuronium $\left(0,6\right.$ et $\left.0,9 \mathrm{mg} \cdot \mathrm{kg}^{-1}\right)$ et de la succinylcholine (1,5 $\mathrm{mg} \cdot \mathrm{kg}^{-1}$, précédée de $0,06 \mathrm{mg} \cdot \mathrm{kg}^{-1}$ de rocuronium) aux muscles masséter et adducteur du pouce.

Méthode : L'étude randomisée a porté sur 60 fernmes d'état physique ASA I ou II, de 18-65 ans, qui ont reçu une anesthésie avec propofol, fentanyl et un mélange de protoxyde d'azote et d'oxygène. L'accéléromyographie simultanée des muscles masséter et adducteur du pouce a servi au monitorage neuromusculaire. Le début d'action a été mesuré aux deux muscles en utilisant une stimulation unique de $0,1 \mathrm{~Hz}$ (pulsation d'onde carrée d'une durée de $0,2 \mathrm{~ms}$ ).

Résultats : Chez toutes les patientes, le blocage neuromusculaire complet s'est produit aux deux muscles testés. Le début d'action a été plus rapide au muscle masséter qu'à l'adducteur du pouce chez les patientes des deux groupes qui ont reçu du rocuronium $(P<0,01)$ et chez celles qui ont reçu la succinylcholine $(P<0,01)$. De plus, le temps d'action a été plus rapide après $0,9 \mathrm{mg} \cdot \mathrm{kg}^{-1}$ de rocuronium $(65 \pm 7 \mathrm{~s})$ qu'après la succinylcholine ( $83 \pm 19 \mathrm{~s}$ ) à l'adducteur du pouce $(P<0,05)$, mais ne présentait pas de différence au muscle masséter $(33 \pm 6$ vs $36 \pm 7 \mathrm{~s})$.

Conclusion : Le début d'action du rocuronium et de la succinylcholine est plus rapide au muscle masséter qu'à l'adducteur du pouce.

From the Clinic for Anaesthesiology and Intensive Care Therapy, Friedrich-Schiller-University, ${ }^{*}$ Jena, Germany, and the Clinic for Anaesthesia and General Intensive Care Medicine, University of Innsbruck, Innsbruck, Austria

Address correspondence to: Dr. Lothar de Rossi, Clinic for Anaesthesiology and Intensive Care Therapy, Friedrich-Schiller-University,

Bachstr. 18, D-07740 Jena, Germany, Phone: +49-3641-933041; Fax: +49-3641-933256; E-mail:derossi@anael lmed.uni-jena.de Accepted for publication August 15, 1999. 
$\mathrm{R}$ OCURONIUM and succinylcholine are appropriate choices to facilitate endotracheal intubation during rapid-sequence induction of anesthesia. ${ }^{1,2}$ Although the ease of endotracheal intubation is influenced by several factors, such as anesthetic induction agents, ${ }^{3}$ depth of anesthesia, and skill of the anesthesiologist, adequate relaxation of the upper airway muscles are required to obtain clinically acceptable intubation conditions.

Among the upper airway muscles, the laryngeal adductor muscles and the masseter muscles are of major importance providing closure of the vocal cords and mouth opening. In addition, the degree of relaxation at the vocal cords (position and movement) and the jaw (degree of relaxation and resistance to laryngoscope) are important criteria in the evaluation of intubating conditions. ${ }^{4}$ At the laryngeal adductor muscles, rocuronium and succinylcholine have a faster onset than at the adductor pollicis muscle ${ }^{5,6}$ Furthermore, onset times following high- dose rocuronium $\left(1.2 \mathrm{mg} \cdot \mathrm{kg}^{-1}\right)$ and succinylcholine (1.0 $\left.\mathrm{mg} \cdot \mathrm{kg}^{-1}\right)$ at the laryngeal adductor muscles are related closely to the development of good intubation conditions within $60 \mathrm{sec}^{7}$ However, even after $1.2 \mathrm{mg} \cdot \mathrm{kg}^{-1}$ rocuronium, the onset time is delayed at the laryngeal muscles compared with $1.0 \mathrm{mg} \cdot \mathrm{kg}^{-1}$ succinylcholine. ${ }^{7}$

Although the function of the masseter muscle is clinically important during the course of tracheal intubation, the onset of action of rocuronium-induced neuromuscular block at this muscle has not been measured. For succinylcholine, there is only one study showing that onset following a small dose of $0.1 \mathrm{mg} \cdot \mathrm{kg}^{-1}$ is more rapid than at the adductor pollicis muscle. ${ }^{8}$

Therefore, the aim of this study was to determine the onset and lag-time of rocuronium- and succinylcholine- induced neuromuscular block at the masseter and at the adductor pollicis muscles in adults.

\section{Methods}

After approval by the Ethics Committee at Jena University, we studied 60 ASA I-II consenting women (aged 18-60 yr), scheduled for elective surgery under general anesthesia. Patients with neuromuscular diseases, or receiving medication known to interfere with neuromuscular transmission were excluded from this study. Midazolam, $7.5 \mathrm{mg}$ was given orally $1 \mathrm{hr}$ prior to induction of anesthesia. Anesthesia was induced using propofol $3 \mathrm{mg} \cdot \mathrm{kg}^{-1}$ and fentanyl $3 \mu \mathrm{g} \cdot \mathrm{kg}^{-1}$, and maintained with propofol 3-5 $\mathrm{mg} \cdot \mathrm{kg}^{-1} \cdot \mathrm{hr}^{-1}$ and $65 \%$ nitrous oxide in oxygen. Nasotracheal intubation was performed without a relaxant. Non-invasive arterial blood pressure, ECG, oxygen saturation, esophageal and skin surface temperature at the sites of stimulation were con- tinuously monitored. Hypothermia (esophageal temperature $<36^{\circ} \mathrm{C}$, skin temperature $<33^{\circ} \mathrm{C}$ ) was prevented by surface air warming (Warmtouch $®$, Mallinckrodt).

Onset of neuromuscular block was monitored at the masseter muscle (MM) and adductor pollicis muscle (AP) with acceleromyography (TOF-Guard®, Biometer International, Odense, Denmark) using supramaximal single twitch stimulation $(0.2 \mathrm{~ms}$ duration) at $0.1 \mathrm{~Hz}$. All numerical neuromuscular data were recorded on a memory card and analysed using TOF Guard Reader software (Biometer International, Odense, Denmark). The start of injection of the muscle relaxant was designated as time zero. Branches of the left mandibular nerve were stimulated $1-2 \mathrm{~cm}$ anterior to the ear lobe under the zygomatic arch and near the mandibular notch as previously described. ${ }^{9}$ The accelerometric probe was fixed at the tip of the chin, approximately $1-2 \mathrm{~cm}$ under the lower lip. The orientation of the probe was fixed so that the axis of the measurement was parallel to the acceleration generated by the contraction of the masseter muscle. For the adductor pollicis, the right ulnar nerve was stimulated at the wrist through skin surface electrodes and the accelerometric probe was fixed at the thumb. In accordance with the rules set out by the Copenhagen Consensus Conference on Good Clinical Research Practice for the investigation of muscle relaxants we allowed at least $10 \mathrm{~min}$ for signal stabilisation of the evoked response prior to the administration of the muscle relaxant. ${ }^{4}$ In addition standard cardiovascular parameters (systolic arterial pressure (SAP), diastolic arterial pressure (DAP), mean arterial pressure (MAP), heart rate (HR) were recorded in all patients before the injection of the muscle relaxants.

Patients were allocated randomly receiving either $0.6 \mathrm{mg} \cdot \mathrm{kg}^{-1}$ rocuronium, $0.9 \mathrm{mg} \cdot \mathrm{kg}^{-1}$ rocuronium or $1.5 \mathrm{mg} \cdot \mathrm{kg}^{-1}$ succinylcholine (preceded by $0.06 \mathrm{mg} \cdot \mathrm{kg}$ ${ }^{1}$ rocuronium four minutes before) over five seconds. The following parameters were measured and calculated at both muscles: 1) time from the beginning of the injection of the muscle relaxant until the first depression of the twitch response (lag-time); (2) maximum block; 3) time from administration of the relaxant to $100 \%$ twitch depression of the twitch response (onset time).

The hypothesis to be tested in this study was that the onset time is different between the masseter and adductor pollicis muscles. We calculated that 15 patients within each muscle relaxant group are necessary to detect a $15 \%$ difference in onset time at the $5 \%$ significance level as previously described by Cohen. ${ }^{10}$ To allow patients to be subsequently excluded from 
the analysis we selected a sample size of 20 patients in each group.

Data are presented as mean (SD). For each muscle relaxant group, we used a Wilcoxon-test to compare the data obtained at the masseter and adductor pollicis. To see differences among the three muscle relaxants groups, data for each muscle were analysed using Kruskal-Wallis-test with post-hoc analysis and Bonferoni correction. Pvalues $<0.05$ were considered to indicate significant differences.

\section{Results}

The study groups did not differ in age, height or weight. The recorded cardiovascular parameters two minutes prior to the injection of the muscle relaxants showed no obvious differences between both groups (Table I). After pretreatment with rocuronium, no muscular fasciculations were seen in the succinylcholine-group.

Rocuronium and succinylcholine produced $100 \%$ block at the masseter and adductor pollicis muscle in all patients. Lag-time and onset time following bolus doses of either $0.6 \mathrm{mg} \cdot \mathrm{kg}^{-1}$ rocuronium, $0.9 \mathrm{mg} \cdot \mathrm{kg}^{-1}$

TABLE I Demographic and cardiovascular data

\begin{tabular}{|c|c|c|c|}
\hline & $\begin{array}{l}\text { Rocuronium } \\
0.6 \mathrm{mg} \cdot \mathrm{kg}^{-1}\end{array}$ & $\begin{array}{l}\text { Rocuronium } \\
0.9 \mathrm{mg}^{\prime} \mathrm{kg}^{-1}\end{array}$ & 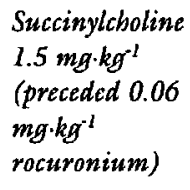 \\
\hline $\begin{array}{l}\text { Age (yr) } \\
\text { Height }(\mathrm{cm}) \\
\text { Weight }(\mathrm{kg}) \\
\text { MAP (mmHg) } \\
\text { Heart rate }(1 \cdot \mathrm{min})\end{array}$ & $\begin{array}{l}42 \pm 9 \\
163 \pm 5 \\
65 \pm 10 \\
74 \pm 6 \\
60 \pm 6\end{array}$ & $\begin{array}{l}42 \pm 11 \\
165 \pm 5 \\
67 \pm 12 \\
74 \pm 6 \\
62 \pm 6\end{array}$ & $\begin{array}{l}41 \pm 12 \\
167 \pm 5 \\
65 \pm 9 \\
75 \pm 8 \\
64 \pm 9\end{array}$ \\
\hline
\end{tabular}

rocuronium, or $1.5 \mathrm{mg} \cdot \mathrm{kg}^{-1}$ succinylcholine was more rapid at the $M M$ than at the $A P$ as shown in Table II. Mean onset time in the $0.6 \mathrm{mg} \cdot \mathrm{kg}^{-1}$ rocuroniumgroup was $49 \pm 11 \mathrm{~s}$ at the $\mathrm{MM}$ and $93 \pm 25 \mathrm{~s}$ at the AP $(P<0.001)$, and in the $0.9 \mathrm{mg} \cdot \mathrm{kg}^{-1}$ rocuroniumgroup $33 \pm 6 s$ at the MM and $65 \pm 17 s$ at the AP ( $P$ $<0.001$ ) (Table II). In the succinylcholine-group the corresponding values were $36 \pm 7 \mathrm{~s}$ at the $\mathrm{MM}$ and 83 $\pm 19 \mathrm{~s}$ at the $\mathrm{AP}$, respectively $(P<0.001)$. In the 0.6 $\mathrm{mg} \cdot \mathrm{kg}^{-1}$ rocuronium-group, both lag-times and onset times were slower compared to the two other two groups $(P<0.01)$. No differences were observed after $0.9 \mathrm{mg} \cdot \mathrm{kg}^{-1}$ rocuronium and succinylcholine regarding onset time at the $\mathrm{MM}$, whereas rocuroniuminduced block was faster at the $\mathrm{AP}$ compared to succinylcholine $(P<0.05)$.

\section{Discussion}

The results of the present study demonstrate that onset of neuromuscular block occurs more rapidly at the masseter than at the adductor pollicis muscle. Complete neuromuscular block at the masseter occured within $60 \mathrm{sec}$ in all patients following bolus injection of either $0.6 \mathrm{mg} \cdot \mathrm{kg}^{-1}$ rocuronium, 0.9 $\mathrm{mg} \cdot \mathrm{kg}^{-1}$ rocuronium or $1.5 \mathrm{mg} \cdot \mathrm{kg}^{-1}$ succinylcholine. This finding seems clinically important, because adequate relaxation of the jaw is one prerequest to achieve good intubation conditions. ${ }^{4}$ Furthermore, the timepoint of complete neuromuscular block at the masseter correlates well with the previously reported rapid development of good intubation conditions following rocuronium and succinylcholine. ${ }^{1,2}$

The observed onset time in this study at the masseter also confirmes the current view that onset of neuromuscular block following rocuronium or succinylcholine is more rapid at the muscles of the upper

TABLE II Lag-time and onset time after rocuronium and succinylcholine

\begin{tabular}{llll}
\hline & $\begin{array}{l}\text { Rocuronium } \\
0.6 \mathrm{mg} \cdot \mathrm{kg}^{-1}\end{array}$ & $\begin{array}{l}\text { Rocuronium } \\
0.9 \mathrm{mg} \cdot \mathrm{kg}^{-1}\end{array}$ & $\begin{array}{l}\text { Succinylcholine } \\
1.5 \mathrm{mg} \cdot \mathrm{kg}^{-1} \\
\text { (preceded } 0.06 \mathrm{mg} \cdot \mathrm{kg}^{-1} \\
\text { rocutronizm) }\end{array}$ \\
\hline Lag-time AP (sec) & & $24 \pm 7$ \\
Range: & $30 \pm 11$ & $21 \pm 7 \mathrm{H \#}$ & $10-40$ \\
Lag-time MM (scc) & $10-50$ & $10-30$ & $17 \pm 6^{\star} \mathrm{I}$ \\
Range: & $20 \pm 7^{\star}$ & $13 \pm 5^{\star} \mathrm{I}$ & $10-30$ \\
Onset time AP (scc) & $10-30$ & $10-20$ & $83 \pm 19$ \\
Range: & $93 \pm 25$ & $65 \pm 7 \mathrm{HI}$ & $40-120$ \\
Onset time MM (sec) & $40-140$ & $40-90$ & $36 \pm 7^{\star} \mathrm{I}$ \\
Range: & $49 \pm 11^{\star}$ & $33 \pm 6^{\star} \mathrm{I}$ & $30-50$ \\
\hline
\end{tabular}

${ }^{*} P<0.01$ : compared to AP

$\dagger P<0.05$ : compared to succinylcholine

$\ddagger P<0.001$ : compared to $0.6 \mathrm{mg} \cdot \mathrm{kg}^{-1}$ rocuronium 
airway, such as the laryngeal muscles, than at the muscles of the hand. ${ }^{5 B 7,11}$ However, the masseter seems to be the only muscle of the upper airway that is reported to be more sensitive than the adductor pollicis muscle to non-depolarizing muscle relaxants, ${ }^{9}$ whereas the laryngeal muscles are known to be more resistant to the effect of non-depolarizing muscle relaxants. ${ }^{6,7,11}$ Accordingly, Fisher et al. ${ }^{12}$ suggested that the difference in onset time is due to a more rapid equilibration between the muscle relaxant plasma concentration and the concentration at the upper airway muscles when compared to the muscles of the hand. However, the impact of the lower resistance of the masseter to non-depolarizing muscle relaxants on speed of onset is still unknown.

Most anesthesiologists may use $1.0 \mathrm{mg} \cdot \mathrm{kg}^{-1}$ succinylcholine without priming with a non-depolarising muscle relaxant to facilitate endotracheal intubation during rapid-sequence induction of anesthesia. Additionally, in most studies comparing intubation conditions with rocuronium, succinylcholine was used without pretreatment of a non-depolarizing muscle relaxant. However, acceleromyography is a very sensitive method and the accuracy of the measurement depends on the recording of a stable twitch response. ${ }^{4}$ Therefore, we used pretreatment with a small dose of rocuronium to avoid artefacts due to succinylcholineinduced fasciculations. Recently, Martin et al. ${ }^{13}$ showed that pretreatment with $0.06 \mathrm{mg} \cdot \mathrm{kg}^{-1}$ rocuronium four minutes prior to the injection of $1.5 \mathrm{mg} \cdot \mathrm{kg}$ ${ }^{1}$ succinylcholine significantly reduced the incidence of muscular fasciculation, but not the incidence of myalgia. Furthermore, in the Martin study intubation conditions were significantly better in the control group (1.5 mg $\mathrm{kg}^{-1}$ succinylcholine) than in the rocuroniumpretreated group.

It is important to note that pretreatment with a nondepolarizing muscle relaxants alters the pharmacodynamic profile of succinylcholine-induced block, including a prolonged onset time, and an increase in the succinylcholine dose up to $50 \%$ is recommended to obtain optimal intubation conditions. ${ }^{14,15}$ Accordingly, we used $1.5 \mathrm{mg} \cdot \mathrm{kg}^{-1}$ succinylcholine to compensate the effect of the rocuronium-priming and to ensure complete neuromuscular block. However, despite the increase in the succinylcholine dose, the onset time at the adductor pollicis was significantly delayed compared to $0.9 \mathrm{mg} \cdot \mathrm{kg}^{-1}$ rocuronium. In addition, without pretreatment onset of action following $1,0 \mathrm{mg} \cdot \mathrm{kg}^{-1}$ succinylcholine is generally faster at this muscles than after rocuronium up to $0.8 \mathrm{mg} \cdot \mathrm{kg}^{-1}$.

In contrast, at the masseter muscle, which function is more important during the course of endotracheal intu- bation than the adductor pollicis, onset time of succinylcholine-induced neuromuscular block after pretreatment was similiar as after $0.9 \mathrm{mg} \cdot \mathrm{kg}^{-1}$ rocuronium. A previous study evaluating the onset of neuromuscular block at the laryngeal muscles with succinylcholine and rocuronium showed that even after $1.2 \mathrm{mg} \cdot \mathrm{kg}^{-1}$ rocuronium onset time is significantly delayed at the laryngeal muscles compared with $1.0 \mathrm{mg} \cdot \mathrm{kg}^{-1}$ succinylcholine. Accordingly, we suggest that the rocuronium-pretreatment may have reduced the speed of onset of succinylcholine-induced block at the masseter, but to a much lesser extend than at the adductor pollicis. On the other hand, succinylcholine is known to increase the tone of the masseter muscle, ${ }^{8}$ which was not observed in our study after pretreatment with rocuronium. However, this finding may not be of clinical relevance in adults, because succinylcholine is known to provide acceptable intubating conditions within 45-60 sec for rapid sequence induction of anesthesia.

In summary, onset and lag-time are faster at the masseter muscle than at the adductor pollicis muscle following rocuronium or succinylcholine. Furthermore, these data support the current view that onset of neuromuscular block occurs more rapidly at the muscles of the upper airway, such as the laryngeal muscles, than at the muscles of the hand.

\section{References}

1 Magorian T, Flannery KB, Miller RD. Comparison of rocuronium, succinylcholine, and vecuronium for rapid-sequence induction of anesthesia in adult patients. Anesthesiology 1993; 79: 913-8.

2 Pïbringer FK, Khuenl-Brady KS, Koller J, Mitterschiffthaler $G$. Evaluation of the endotracheal intubating conditions of rocuronium (ORG 9426) and succinylcholine in outpatient surgery. Anesth Analg 1992; 75: 37-40.

3 Sparr HJ, Giesinger S, Ulmer $H$, Hollenstein-Zacke $M$, Lnger TJ. Influence of induction technique on intubation conditions after rocuronium in adults: comparison with rapid-sequence induction using thiopentone and suxamethonium. Br J Anaesth 1996; 77: 339-42.

4 Viby-Mogensen J, Engbak J, Eriksson LI, et al. Good clinical research practice (GCRP) in pharmacodynamic studies of neuromuscular blocking agents. Acta Anaesthesiol Scand 1996; 40: 59-74.

5 Meistelman $C$, Plaud B, Donati F. Neuromuscular effects of succinylcholine on the vocal cords and adductor pollicis muscles. Anesth Analg 1991; 73: 278-82.

6 Meistelman C, Plaud B, Donati F. Rocuronium (ORG 9426) neuromuscular blockade at the adductor muscles of the larynx and adductor pollicis in humans. Can J Anaesth 1992; 39: 665-9. 
7 Wright PMC, Caldwell JE, Miller RD. Onset and duration of rocuronium and succinylcholine at the adductor pollicis and laryngeal adductor muscles in anesthetized humans. Anesthesiology 1994; 81 : 1110-5.

8 Smith CE, Donati E, Bevan DR. Effects of succinylcholine at the masseter and adductor pollicis muscles in adults. Anesth Analg 1989; 69: 158-62.

9 Smith CE, Donati F, Bevan DR. Differential effects of pancuronium on masseter and adductor pollicis muscles in humans. Anesthesiology 1989; 71: 57-61.

10 Coben J. Statistical Power Analysis for the Behavioral Sciences, 2nd ed. Hillsdale, NJ: Lawrence Erlbaum Associates, 1988.

11 Donati F, Meistelman C, Plaud B. Vecuronium neuromuscular blockade at the adductor muscles of the larynx and adductor pollicis. Anesthesiology 1991; 74: 833-7.

12 Fisher DM, Szenohradszky J, Wright PMC, Lau M, Brown $R$, Sharma $M$. Pharmacodynamic modelling of vecuronium-induced twitch depression. Anesthesiology 1997; 86: 558-66.

13 Martin $R$, Carrier J, Pirlet $M$, Claprood $\Upsilon$, Tétrault J $P$. Rocuronium is the best non- depolarizing relaxant to prevent succinylcholine fasciculations and myalgia. Can J Anaesth 1998; 45: 521-5.

14 Freund FG, Rubin $A P$. The need for additional succinycholine after d-tubocurarine. Anesthesiology 1972; 36: 185-7.

15 Blobner M, Schneck HJ, Busley R, Schneider G, JelenEsselborn $S$, Kochs $E$. The influence of precurarization with different doses of atracurium and vecuronium on the pharmacodynamics of succinylcholine. Anesthesiology 1996; 85(Suppl3a): A848. 